\title{
Transient expression of virus-like particles in plants: a promising platform for rapid vaccine production
}

\author{
Mohammadzadeh $\mathbf{S}^{1}$, Rahimi $\mathbf{S}^{2}$, Ebrahimi-Rad $\mathbf{M}^{3}$, Ofoghi $\mathbf{H}^{4}$, Ehsani $\mathbf{P}^{2 *}$ \\ ${ }^{1}$ Medical Biology Research Center, Kermanshah University of Medical Sciences, Kermanshah, Iran. \\ ${ }^{2}$ Molecular biology Department, Pasteur Institute of Iran, Pasteur Institute of Iran, Tehran, Iran. \\ ${ }^{3}$ Biochemistry Department, Pasteur Institute of Iran, Pasteur Institute of Iran, Tehran, Iran. \\ ${ }^{4}$ Department of Biotechnology, Iranian Research Organization of science and Technology, Tehran, Iran.
}

\begin{abstract}
Transient expression is an efficient and fast system to express recombinant proteins which has been used in different eukaryotic hosts such as mammalian and plant cells. Several applications of this system have so far been used which expression of proteins of interest is one of them. Recently, plants have attracted attention for being used as hosts for the production of recombinant pharmaceutical proteins such as antibodies and vaccines due to their lower price of production, compared to the mammalian systems. Many studies have conducted on the rapid production of vaccine candidate proteins either as a monomer or virus-like particles during epidemics of fast-spreading diseases such as influenza. Virus-like particles have been expressed in prokaryotic and eukaryotic systems are demonstrated to be one of the best antigen presenting systems which can carry antigens in a safe repetitive format on a particle to induce immunity.. Here, we present recent advances in applying transient expression in plants that can be used to produce naked or enveloped virus-like particles as vaccine candidate as well some clinical trial studies.
\end{abstract}

KEYWORDS: plant-made vaccine, transient expression, virus-like particles.

\section{INTRODUCTION}

Infectious diseases are responsible for $16 \%$ of total deaths worldwide [1]. More than 30 million children are not immunized against preventable infectious diseases [1]; therefore, search for the production of inexpensive while effective vaccines are ongoing with high priority. During the last decades, the invention of DNA-based technologies and discovery of plant expression systems have enhanced plant application as bioreactors for the production of heterologous proteins. For instance, transgenic tobacco has been used for production of human serum albumin [2]. Plants have been used to express other therapeutic proteins at laboratory scale for products such as blood components, growth factors, hormones, cytokines, vaccines and antibodies [3-6]. Vaccines have been a major part of pharmaceutical proteins produced in plants. More than 20 out of 30 plant-produced antigens from pathogens of protozoan, viral and bacterial origins have been shown to induce mucosal and systemic immune responses in laboratory animals as well clinical trials, in either the monomer or the virus like-particles forms [7-8]. In 2006, the first plant-

*Corresponding Author: Parastoo Ehsani, Molecular biology Department, Pasteur Institute of Iran, Pasteur Institute of Iran, Tehran, Iran.

Email: p_ehsani@yahoo.com

Tel/Fax: (+98) 2164112803/ (+98) 2164112219 produced subunit vaccine against Newcastle disease of the poultry was approved by the US Department of Agriculture Center for Veterinary Biologics which could be industrialized [9] For many years, most of the recombinant proteins were expressed in transgenic plants; however recently, transient expression has been demonstrated to overcome the limitations of stable expression systems and have brought new advantages to plants as expression systems hosts [10]. The objective of the present study was to review transient expression system in plants for production of vaccine candidate proteins and its application as a rapid system in vaccine production industry.

1- Plant transient expression system; the pros and cons The first attempts to produce recombinant proteins for agricultural, pharmaceutical and environmental applications were based on transgenic plants [11]. The major purpose was to bear a genetically modified plant and scale up the production of the proteins of interest using agricultural systems. In order to transfer the gene of interest, several techniques such as engineered Agrobacteria, biolistic and electroporation have been introduced which could target different plants, organs and organelles [12]. Agrobacteria, the world's smallest genetic engineer, is the most used vehicle for transferring and integrating an expression cassette into a plant genome. The expression cassette used by the above-mentioned technique 
contained antibiotic resistance gene for selection of the transformed plant cells. The single transformed cell could grow to a full plant through regeneration techniques [13]. However, some implications of producing transgenic plants, such as complexity of transforming process, time needed for regeneration of transformed plant cell, low expression level and environmental concerns have shifted the studies to alternative approaches such as transient expression system [10].

The transient expression technique was first introduced to study the regulatory elements including the promoters and the terminators, as well as the ability of the plant cells to express heterologous genes [14]. The first reported transient expression was conducted by Horsch and Klee in 1986 for rapid assay of agrobacterial opine genes expression in the leaves which had been transformed by Agrobacterium tumefaciens. The leaf discs were only tested for the transient expression, three days after the incubation and the plants were no further regenerated [15]. In the same year, transient expression of firefly gene in carrot protoplast was carried out, using electroporation technique [14]. However, the rapid production process of the target protein encouraged the researchers to ameliorate the technique for research and further commercial applications [16].

In the transient expression system, DNA is introduced into the plant cells by using either PEG (for protoplast), viruses or Agrobacteria. As a result, the genetic material enters into the plant cells and there is no need for gene insertion for the expression, as it remains transcriptionally active for several days [10]. The advantages of agrobacterial-mediated transient expression systems are their high speed, high yield, low cost, potential for producing toxic proteins, lack transgene release into the nature, as well as ease of scalability and monitoring during their biological manufacturing in plants [17] (Fig. 1).
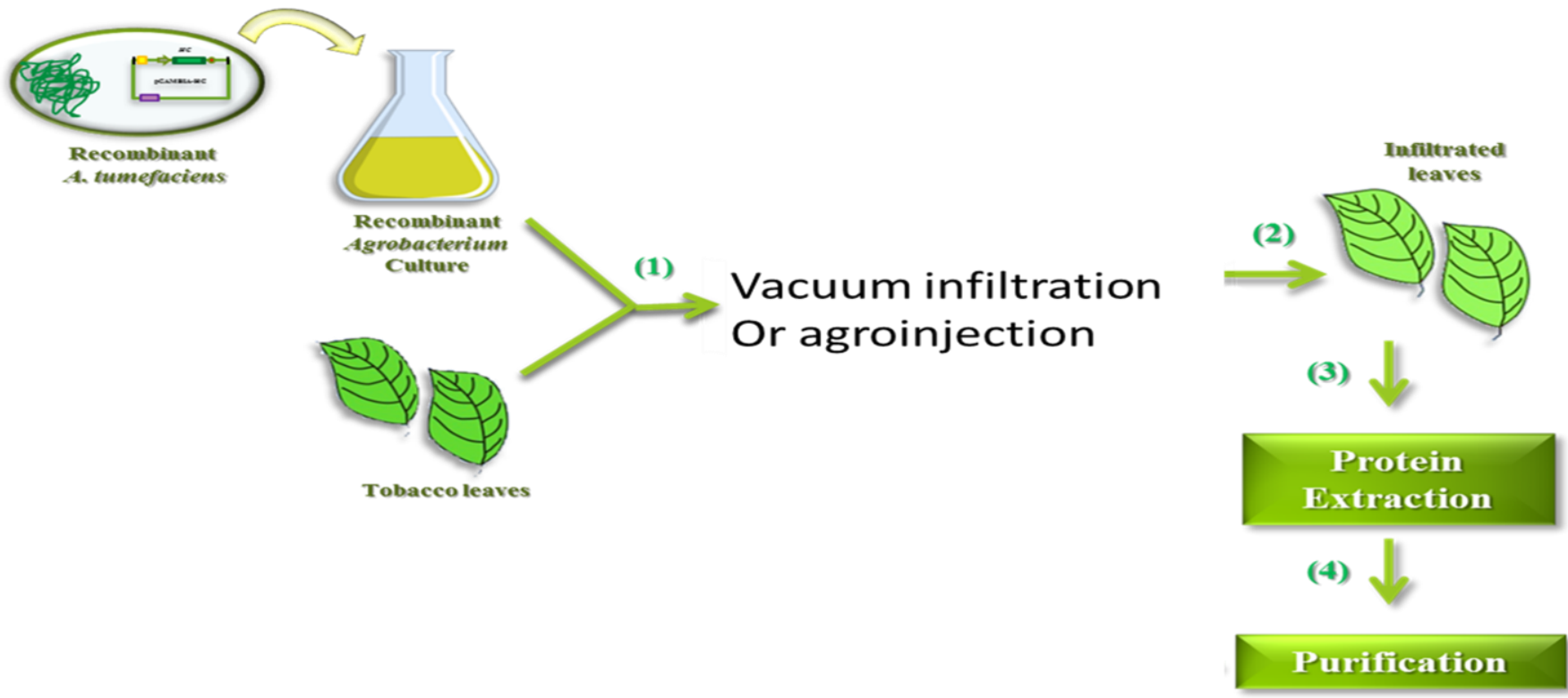

Fig. 1. Transient expression of target gene in tobacco leaves by Agro-infiltration. Recombinant Agrobacterium cell cultures transformed with the vector containing gene of interest are prepared for transient assay. 1) Tobacco leaves are immersed in Agrobacterium cell suspensions and infiltration is carried out by a continuous vacuum and for agroinjection by a needleless syringe the Agrobacteria are infiltrated into leaves. 2) The infiltrated leaves are incubated at $24^{\circ} \mathrm{C}$ under light-dark cycles for three days. 3,4 ) Leaves are subjected to protein extraction and purification.

However, agrobacterial-mediated transient expression systems have also some disadvantages. For instance, the presence of bacterial debris such as Agrobacterium lipopolysaccharides, though observed as non-pyrogenic, can be obtained in the final product [18]. Agrobacterium host specificity results in low levels of transformation in certain plant species, which can be regarded as another limitation [19]. Nevertheless, a variety of proteins have been produced using the transient expression system, including antibodies, growth factors and vaccine candidate proteins in two conformations of monomer and viruslike particles [20-25]. In addition to the intrinsic characteristic of the gene of interest, the other two elements that have impacts on the transient expression of vaccine candidate proteins in the plant are the host and the vector used which will be discussed as follows.

\section{a- The hosts used for transient expression}

A variety of plant species, including spinach, lettuce, tobacco, arabidopsis and medicinal plants have been used as the host for the transient expression systems [26-27]. Among them, Nicotiana (N.) has been the most frequently used plant, as it produces high leaf biomass and its transformation and growth culture system are easy to handle [28]. N. benthamina, an allopolyploid with 19 chromosomes of $3100 \mathrm{Mbp}$ in size, is an indigenous Australian regional cultivar [29-30]. Because of its susceptibility to plant viruses and pathogens, it is the most widely used host for virus-based expression vectors, expression of viral as well as bacterial proteins, detection of viral-induced gene silencing and transient protein expression experiments. Moreover, it can be easily transformed genetically and regenerated with high efficiency which can be optimized for expression of heterologous genes [30].

Different techniques have been used for delivery of the expression vectors to the cells, such as viruses, PEG, gene-gun, agro-injection and agro-infiltration [31-33]. Furthermore, the plants that are used for transient expression could be either in the protoplast, the whole plant cell, the tissue culture sample, the callus or the fresh leaves. Furthermore, the expression vectors have been ameliorated for high yield and commercial expression of heterologous proteins in recent years [34].

b-The vectors used in plant transient expression:

The transient expression vectors have been evolved and highly adaptable regulatory elements of the plants and their pathogens 
have been used [35-36]. The early vectors of this system contained Agrobacteria, plant or viral originated promoters and terminators. These vectors were used to test the expression constructs in protoplast transient expression system. The protoplast was prepared following a cell wall enzymatic digestion of the plant cell and transformation was carried out using polyethylene glycol [37] or electroporation [38]. The sterility of the process and difficulty in protoplast survival after transformation were major difficulties in the application of protoplasts as a transient expression system. The weak point of the first vectors used in both transgenic and transient expression systems was the low amount of expression; therefore, after protoplasts, viruses were used for transient expression systems. Several DNA and RNA viruses such as tobacco mosaic virus (TMV; Fig. 4), potato virus X (PVX), cowpea mosaic virus (CPMV) and alfalfa mosaic virus (AlMV) were among the most used viruses. These vectors are composed of single and multiple-expression cassettes for the production of simple or multi-subunit proteins [10]. The major problem of using a whole virus was the packaging limitation for integration of the gene of interest that could cause the loss of transgene and instability of the viral vector, as well as environmental concerns about the release of modified virus. In addition, the production process of the gene of interest takes 3-4 weeks [39]; which limits the use of this technology for large scale production purposes.

One of the highly utilized vectors in research and industry is originated from Agrobacteria binary vectors. It is based on Agrobacterium $120 \mathrm{kbp}$ tumor inducing (Ti) plasmid. Binary system is based on engineered Ti plasmid as a helper plasmid which carries the virulence genes and a shuttle vector containing transfer DNA (T-DNA; Fig. 2) which carries expression cassette between left and right borders (LB, RB). Following activation of Agrobacteria by phenolic compounds such as acetosyringon and after vacuum infiltration or injection,
Agrobacteria passes through the leaf barriers and allocates itself near the plant cells to transfer T-DNA into the cells (Fig. 1). Using the capacity of Agrobacteria to transfer long stretches of DNA has provided the possibility of transferring the viral genome by T-DNA. There are four versions of expression vectors that are constructed for Agrobacteria mediated transient expression:

In the first version vectors, some viral regions were present in T-DNA in addition to the cloned genes such as the promoter. The weak point of the first vectors such as PBI121 for transient expression was the fact that the expression yield was very low [40-42](Fig. 2B). The second version of transient expression vectors were non-replicative viral-based vectors which applied a set of regulatory elements of plant viruses in T-DNA around the gene of interest in which non-essential viral functions were eliminated [43-46] (Fig. 2C). In the non-replicative vectors, less amount of the transcript is produced compared to the replicative forms, as shown in Fig. 2A, C. The third version was replicative vectors in which following agroinfiltration, these vectors continue the get processed by replication in cytoplasm; therefore, their copy number increases and produce high amount of the transcript. As a result, the total count of recombinant protein will increase geometrically [44] (Fig. 2A). In the above systems, the expression begins 3 hours after DNA delivery by Agrobacteria and peaks at 48 hours and the process continues for 10 days. The major advantages of these systems are their speed, high yield of proteins, low cost, scalability and high control of both upstream and downstream processing and lack of transgenic plant production [47-49]. The fourth version which is another non-replicating vector is pEAQ hypertranslational expression system, based on the RNA-2 of cowpea mosaic virus (CPMV). The advantage of this version is its high recombinant protein production, hence high translational efficiency without the need for viral replication [50] (Fig. 2D).

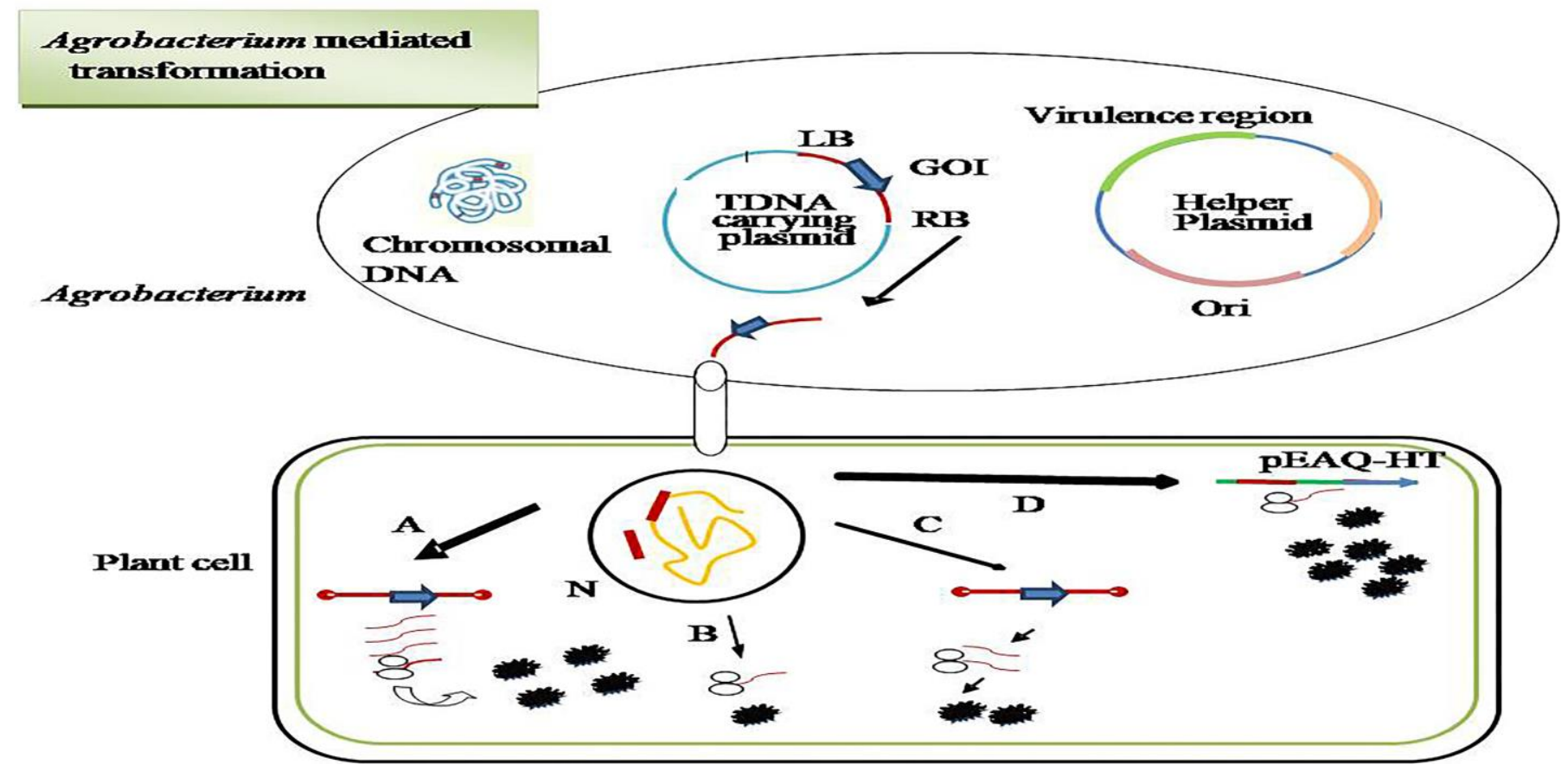

Fig. 2. Destiny of T-DNA containing expression vector/cassette mediated by Agrobacterium; A) Transient expression of replicative vector located in T-DNA produces several template for transcription and many mRNA. B) Stable expression following genome integrated T-DNA. C) Transient expression of non replicative vector in T-DNA producing mRNA. D) pEAQ-HT system hypertranslational expression system. GOI: Gene of interest, Ti plasmid: Tumor inducing plasmid, RB: Right border, LB: Left border, N: Plant nucleous, Ori: Agrobacteria origin of replication. 
Several antibodies, vaccine candidates and other pharmaceutical proteins have been produced in research laboratories using agroinfiltration technique [10, 20, 51, 21]. Moreover, the optimized large scale version has been used for fast and high concentration production of proteins at industrial level by several companies [52-54]. Several vaccine candidate proteins have been expressed via transient expression including, Influenza virus-like particles, hepatitis B surface antigen and Shigella IpaB. These candidate vaccine proteins have been produced as subunit vaccines in two forms of soluble proteins (SP) and virus-like particles (VLP), which will be discussed in more details as follows:

\section{2-Vaccine candidates produced based on plant transient expression systems}

Subunit vaccines contain purified antigens of an organism that elicit protective immunity. They could be toxoids, subcellular fragments or surface antigens. Recombinant DNA technology has been used to produce recombinant subunit vaccines in different hosts [55]. The development of subunit vaccines using genetic engineering has substituted whole pathogen vaccines in most of the cases and has diminished their associated safety risks [56]. In 2000, the expression of vaccine candidate proteins in transgenic plant was patented for the first time (US6034298A). Later, the need for a fast production system during pandemics, supported rapid vaccine manufacturing techniques, such as the plant transient system. Table 1 displays examples of vaccine proteins, produced through plant transient expression system for both monomer and virus like particles. Transient expression strategies have been used to express both soluble and self-assembling antigens in plants. They generally increase the expression levels significantly higher than those obtained through nuclear transformation [57]. There are several advantages for each strategy that are reviewed below.

Table 1. Production of subunit and VLP vaccine using plant transient expression

\begin{tabular}{|c|c|c|c|c|c|}
\hline Vaccine format & $\begin{array}{c}\text { Immunogen/ } \\
\text { vaccine }\end{array}$ & Components & $\begin{array}{c}\text { Transient expression } \\
\text { platform / yield }\end{array}$ & Route/ immune response & Ref \\
\hline \multirow{3}{*}{$\begin{array}{l}\text { Monomer } \\
\text { (subunit) }\end{array}$} & $\begin{array}{l}\text { E1E2 heterodimer/ } \\
\text { HCV }\end{array}$ & $\begin{array}{l}\text { The wild-type dimer } \\
\text { (E1E2) or an E2 N- } \\
\text { glycosylation mutant } \\
\text { (E1E2 } \Delta \mathrm{N} 6)\end{array}$ & $\begin{array}{c}\mathrm{pEAQ}-H T \\
\text { Lactuca sativa }\end{array}$ & $\begin{array}{l}\text { Oral / induction humoral } \\
\text { immune response in mice }\end{array}$ & $\begin{array}{l}\text { Clarke } 2017 \\
{[58]}\end{array}$ \\
\hline & M2e/ influenza & $\begin{array}{c}\text { Flagelin STF2-4xM2e } \\
\text { fusion } \\
\text { (flagellin of } S \text {. } \\
\text { typhimurium asTLR5 } \\
\text { ligand adjuvant fused to } \\
\text { four copies of the M2e } \\
\text { peptide of influenza A } \\
\text { virus) }\end{array}$ & $\begin{array}{c}\text { PVX } \\
\text { Nicotiana benthamiana } \\
1 \mathrm{mg} / \mathrm{g} \text { FLW or 30\% TSP }\end{array}$ & $\begin{array}{l}\text { Intranasal / induction specific } \\
\text { antibodies and protection } \\
\text { against infulanza challenge }\end{array}$ & $\begin{array}{l}\text { Mardanova, } \\
2015 \text { [59] }\end{array}$ \\
\hline & $\begin{array}{c}\text { Pfs } 25, \\
\text { Pfs230_C0/malaria }\end{array}$ & $\begin{array}{l}\text { Pfs } 25 \text { and the } \mathrm{C} 0 \text { - domain } \\
\text { of Pfs } 230 \text { fusion protein }\end{array}$ & $\begin{array}{l}\text { pTRAkc-ERH } \\
N . \text { benthamiana } \\
\text { 300mg/g FLW }\end{array}$ & $\begin{array}{c}\text { Intraperitoneal/ Induce } \\
\text { antibodies with transmission } \\
\text { blocking activity }\end{array}$ & $\begin{array}{l}\text { Beiss, } 2015 \\
{[60]}\end{array}$ \\
\hline \multirow[b]{3}{*}{$\begin{array}{l}\text { Viruse like } \\
\text { particle }\end{array}$} & $\begin{array}{l}\text { structural proteins } \\
\text { (VP0, VP1 and VP3)/ } \\
\text { Foot-and-mouth } \\
\text { disease }\end{array}$ & $\begin{array}{c}\text { The viral capsid precursor } \\
\text { P1-2A without the } 3 \mathrm{C} \\
\text { protease. }\end{array}$ & $\begin{array}{c}\text { pEAQ-HT } \\
N . \text { benthamiana } \\
\sim 0.03 \text { } \mu \text { g per gram of } \\
\text { FLW } \\
\end{array}$ & $\begin{array}{l}\text { Subcutaneous / stimulate the } \\
\text { production of FMDV-specific } \\
\text { antibodies }\end{array}$ & $\begin{array}{l}\text { Veerapen, } \\
2018[61]\end{array}$ \\
\hline & $\begin{array}{c}\text { HA from the } \\
\text { A/Indonesia/05/05 } \\
\text { (H5N1) }\end{array}$ & $\begin{array}{c}\text { H5 HA } \\
\text { (H5 Hemagglutinin) }\end{array}$ & $N$. benthamiana & $\begin{array}{l}\text { Intranasal / protection against } \\
\text { the viral challenge }\end{array}$ & $\begin{array}{c}\text { Major, } 2015 \\
{[62]}\end{array}$ \\
\hline & $\begin{array}{l}\mathrm{NaVCP} / \text { Human } \\
\text { norovirus }\end{array}$ & $\mathrm{NaVCP}$ & $\begin{array}{l}\text { TMV-based ICON } \\
\text { expression vector } \\
\sim 0.3 \mathrm{mg} / \mathrm{g} \text { FLW }\end{array}$ & $\begin{array}{l}\text { Intranasal / induction } \\
\text { significant mucosal and serum } \\
\text { antibody response }\end{array}$ & $\begin{array}{c}\text { Mathew } 2014 \\
\text { [63] }\end{array}$ \\
\hline
\end{tabular}

FLW- Fresh leaf weight, TSP-Total soluble protein

\section{a- Monomer (soluble) subunit vaccine candidate}

The first original article on this subject indicated the expression of a structural protein, named VP1 of foot-and-mouth disease that used a TMV-based vector and had a yield of almost $0.5-1$ $\mu \mathrm{g} / \mathrm{g}$ of fresh weight [64]. Progress in transient expression techniques involved modular deconstructed expression systems, codon optimization, targeting protein to particular subcellular compartments, exploitation of silencing suppressors and finding the optimal harvesting time [65-66]. Therefore, using TMVbased vector and substituting the coat protein with tuberculosis antigen, was able to increase the yield to $800 \mu \mathrm{g}$ of the recombinant antigen per gram of fresh leaf tissues [67]. The ability of plant-derived subunit vaccines to induce immune responses has been confirmed in other studies such as a recent article in which oral delivery of a plant-made E1E2 dimers of hepatitis $C$ virus has been reported to induce a specific systemic and mucosal humoral immune responses in mice, following an intramuscular priming [58]. In another study, a transientlyexpressed chimeric protein, consisting of flagellin and M2e antigen from influenza A virus (flagellin-M2e) expressed in Nicotiana benthamiana, using a self-replicating PVX based viral vector, conferred high levels of M2e-specific serum antibodies and protection against lethal challenges with different strains of influenza virus in mice through intranasal immunization [59]. In a recent study, subcutaneous injection of tobacco-derived envelope (E) protein of Zika virus has been shown to elicit potent neutralizing immune responses in mice [68].

Such recombinant subunit vaccines that are based on vaccination with a single viral protein or peptide have also indicated some drawbacks, such as not being efficient to present a native conformation which would be less immunogenic than the whole pathogen. Consequently, their administration often needs larger amount of antigens, more 
doses and co-delivery of adjuvants [69]. Therefore, they could be costly to be used for extensive vaccination programs. This issue is particularly important in terms of veterinary vaccines where the cost of a vaccine must be evaluated regarding the value of the vaccinated animal [69]. Despite all these problems, Fraunhofer USA (http://www.fraunhofer.org/MolecularBiotech nology), has demonstrated that transient expression of HA of H1N1(H1N1; 2009 pandemic) influenza virus in monomer form in $N$. benthamiana has been successful in phase I of the clinical trials [70].

\section{b- VLP as vaccine candidates}

Inactivated or live-attenuated viruses are the most effective vaccines to stimulate both cellular and humoral immune responses; however, there are always concerns about reversion of the live-attenuated vaccines to their pathogenic forms [71]. In VLP production system, the gene of interest coding for the antigenic epitopes or peptides which may range in size from a few amino acids up to more than 150 residues, will be fused to the viral coat protein. Therefore, the viruses will present the epitopes on their surfaces. The advantages of VLP strategy are the ease of their purification and their enhanced immunogenicity due to the peptide epitopes presented on their surfaces.

The hosts to express VLPs may include plants, E. coli, mammalian cells, yeast and bacuolaviruses [72-73]; however, each host has its own limitations for high level production of VLPs.

The mammalian and insect cells are the preferred systems to perform appropriate complex mammalian-type post translational modifications (PTMs) and folding. They also work well for non-enveloped and enveloped VLPs. However, there are also limitations associated with them, such as low yield, high cost, difficult scalability and vulnerability to infection with mammalian pathogens or contamination of the product with enveloped baculovirus particles. Bacteria- and yeast-based VLP expression systems are less expensive and have a simple scaleup process; however, due to the lack of mammalian-like PTM for bacteria and high mannose modification in yeast host, some recombinant proteins cannot get ideal results and immunogenicity. Moreover, enhanced safety precautions are required in these systems as well. On the other hand, transient plant expression system could be attractive for its rapid expression, high scalability, cost-effectiveness and lack of mammalian pathogens, as well as its support for most protein folding and eukaryotic PTM [74-75]. Furthermore, some limitations such as low VLP expression in transgenic plants could be resolved using transient expression and plant with humanized glycosylation [76].

The assembly of VLPs is based on physico-chemical characteristics of capsid proteins that could shape compartments mimicing viruses; therefore, VLPs are designed to mimic the original virus without infectious genomic material of human viruses [75]. There are two frameworks for the VLPs: First: The mammalian-originated VLPs: these VLPs should be replication-deficient and non-infectious [69]. They have been indicated to be effective vaccines to stimulate strong B- and Tcell-mediated immune responses, not only as vaccines themselves, but also as carriers for effective presentation of foreign epitopes during immunization [51, 56] (Fig. 3).

Second: despite technical definitions, replicating plant virus could also be considered as VLPs because of the non-infecting properties present in the animal cells. Thus, for vaccine purposes, a chimeric plant virus has been used as a nanoscale carrier to display heterologous epitopes of animal pathogens [77] (Fig. 4).VLPs have revealed to be a safe and effective approach to induce neutralizing antibodies against their surface proteins where the subunit soluble forms have failed to display epitopes on a surface and stimulate antibody production [51]. There are several plant viruses that are used as a framework for presenting antigens such as TMV, PVX and geminiviruses [51, $24,69,78,73,79]$. In various studies, the adjuvant properties of the plant virus have also been confirmed such as the one in which the protective antigens on TMV was investigated for immunization against tularemia infection [80].

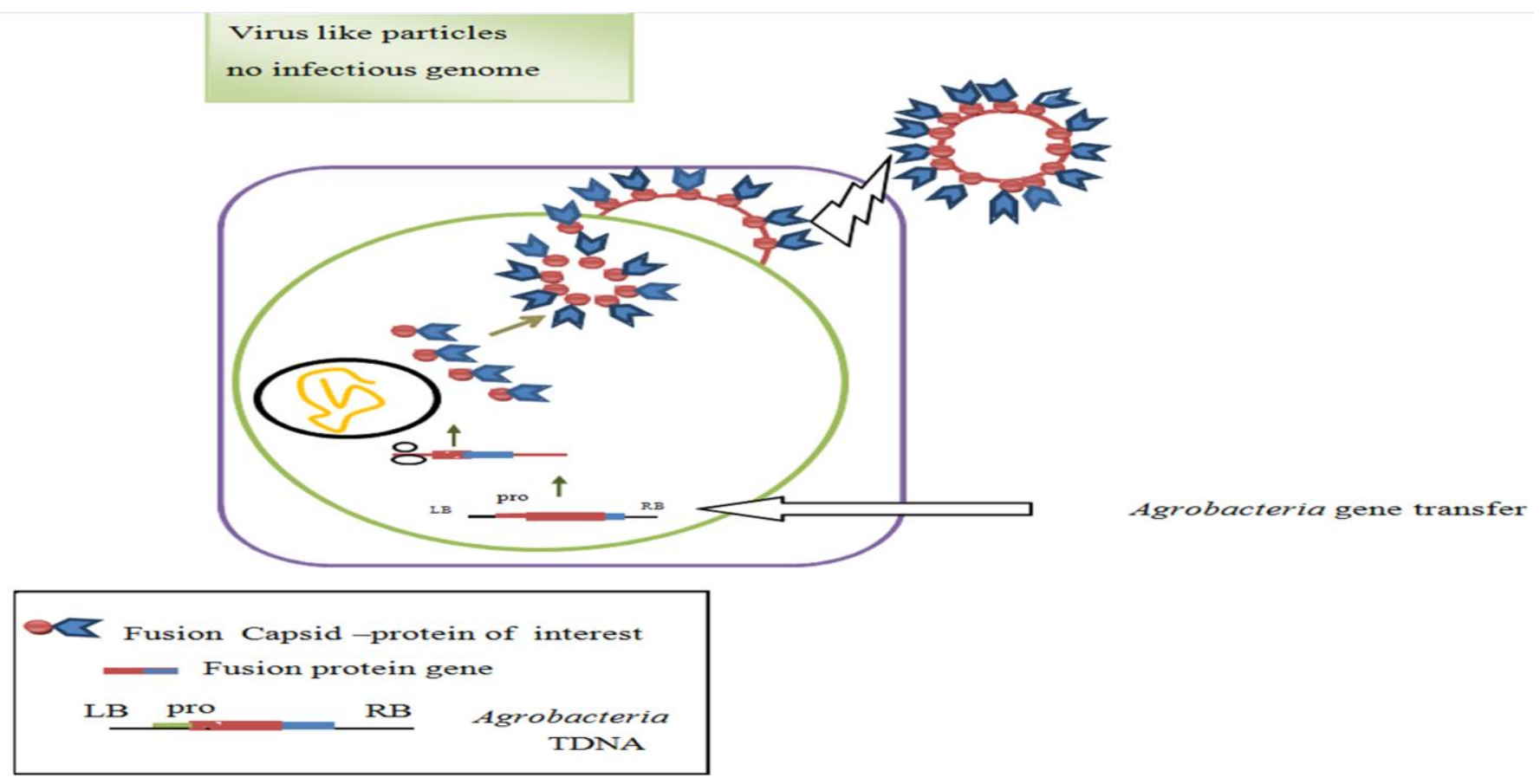

Fig. 3. Virus like particle production mediated by Agrobacterium expression system. The T-DNA carrying gene of interest fused to a viral coat protein. Capsid intrinsic potential to assemble will produce non infectious virus like particles from expressed fusion protein. 

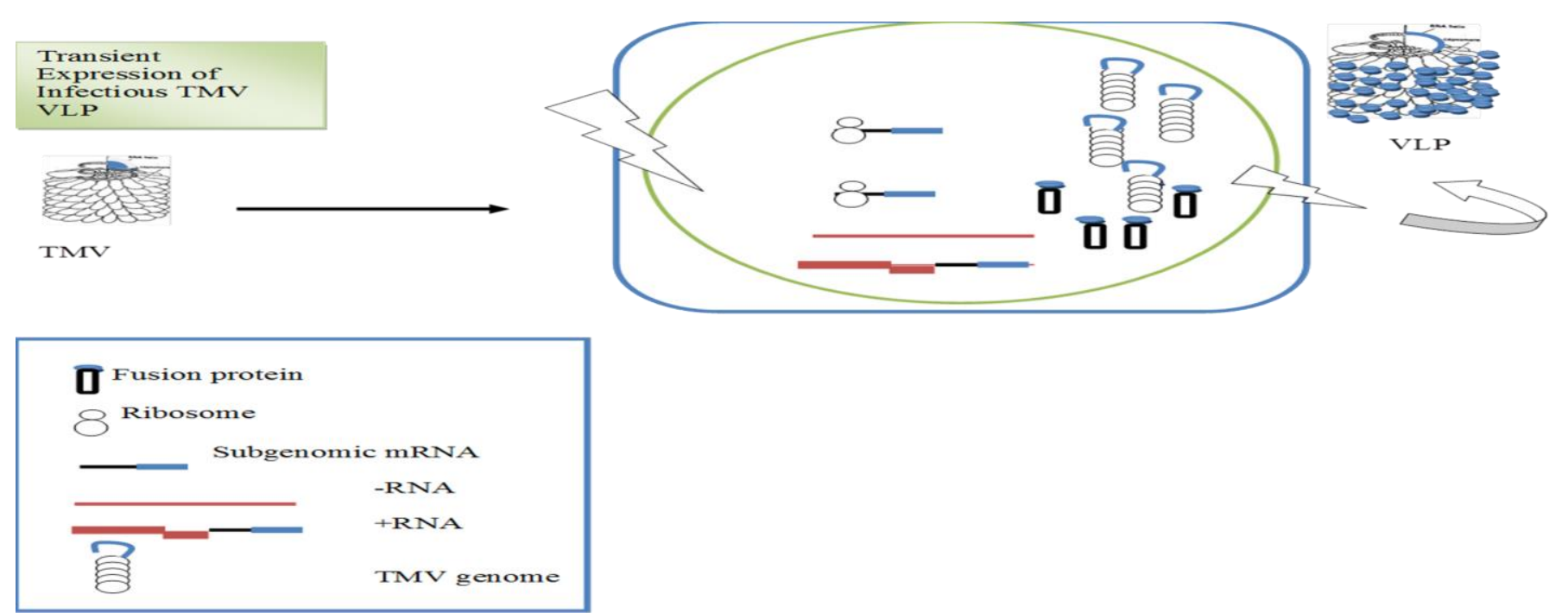

Fig. 4. Production of Tobacco Mosaic virus based Virus like particle: Following decapsidation, high amount of viral negative and positive RNA will be produced. Later subgenomic mRNA will be translated into fusion protein composed of coat protein and protein of interest. The virus like particles will be assembled into an infectious replicative virus carrying protein of interest.

\section{3-Limitations of current VLP production platforms}

The production of chimeric viral particles with efficient virion assembly has been the objective of several studies. To achieve this, certain methods have been based to limit the steric hindrance of the modified coat protein by incorporation of the linker peptides between the viral coat protein and the fused peptide [81]. Furthermore, applying proteolytic site region, suppressed stop codon, "ribosomal skip" of translation sequences (such as $2 \mathrm{~A}$ peptide of the foot-and-mouth disease virus) between the heterologous peptide and the coat protein have been used where the fused product is synthesized along with the wild type coat protein [82]. Another problem for enveloped VLP is budding through the cell membrane. To overcome this problem, tobacco leaves producing Influenza VLP could be treated with an enzyme to loosen the cell wall and the budding which can also increase the purification yield [83].

\section{4- Plant-made virus-like particles as vaccine candidates:}

Several virus-based vaccine candidates have been produced in transgenic plants, expressing hepatitis B core antigen ( $\mathrm{HBcAg}$ ) and hepatitis B surface antigen (HBsAg). Moreover, the VLP fused with human papilloma virus (HPV) L-1 has been successfully expressed and assembled.

Depending on the vectors, the expression levels of VLPs could be varied. For instance, deconstructed geminiviral vectors can increase the yield of HBcAg VLPs in N. benthamana, 80 times higher than PVX vectors. On the contrary, TMV-based MagnICON vector shows 3 times higher yield for HBcAg VLP than the geminiviral vector [56].

Despite all the efforts in research studies, rapid production of VLP in plant was not practiced until 2009. Due to 2009 H1N1 swine flu pandemic, the national need for rapid vaccine manufacturing promoted US government to support production of recombinant vaccines [84]; therefore, $\$ 40$ million were awarded from US Department of Defense to develop transient expression of influenza vaccine in tobacco within 4 to 6 weeks, instead of egg-based systems that takes 6 months to cover the same amount [23]. Interestingly, in 2012, approximately 10 million doses of $\mathrm{H} 1 \mathrm{~N} 1$ vaccine could be produced in one month by this technique. This vaccine candidate was tested in a mouse model and produced protective levels of neutralizing antibodies. The result of animal trials indicated that two doses of plant-produced influenza H5-VLPs could protect mice from lethal virus challenges $[24,23]$. The results of immunogenicity of the vaccine in mice, promoted the plant-made influenza vaccine process to further clinical trials [84].

\section{5- Clinical trials of plant-produced virus-like particles}

The safety and immunogenicity of plant-produced VLPs are now evaluated in preclinical and clinical studies. Recently, the systemic and mucosal immune responses for the Norwalk Virus VLPs expressed transiently in $N$. benthamiana using a TMV expression system have been demonstrated in preclinical studies [72]. Influenza virus is one of the major threats to human populations worldwide. Highly variable surface proteins of hemagglutinin (HA) and neuraminidase (NA) are the components of current vaccines. Each year, new strains emerge that cause pandemics and the stocks of embryonated eggs could not cover the vast needs for the vaccine production. The results of research of last decades on plant transient expression system has indicated that HA antigen could be assembled as a VLP which can elicit protective immune responses in animal models. The surprising successful results have promoted Medicago Inc. (Canada) to develop a large scale production in three weeks; thereby, following emerging of new influenza virus pandemics, the VLP-based vaccine could be prepared in less than a month [62]. Recently this company announced the start of final clinical efficacy study for its plant-derived seasonal quadrivalent influenza vaccine candidate (ClinicalTrials.gov number, NCT03301051). Considering their success in seasonal and pandemic plant-derived influenza vaccines, the company has invested on production of new vaccines, namely rabies, HPV and Norwalk vaccines $<$ http://medicago.com/pipeline-progress/>.

\section{6- Biosafety of plant transiently produced vaccine candidates}

The administration of plant recombinant products in human and animal therapy should be associated with adequate biosafety and testing regulations that are established for all biopharmaceutical products [10]. Since pathogenicity of plant viral vectors has never been demonstrated for mammals, such 
vectors are considered safe for human and animal health; therefore, edible transformed plant tissues may be used to deliver vaccines at mucosal level to eliminate the use of needles. This approach has the advantages of lowering the related costs of the treatments and also would prevent the transmission of blood-borne diseases that may happen through needle injections. Moreover, the antigen can be protected from degradation when encapsulated by plant material during the passage through the intestine [85].

There are many parameters that affect immunization through oral plant vaccines, such as the adjusted dose to prevent oral tolerance for the vaccine while avoiding unexpected allergies [86-88]. Endotoxins, polyphenols and alkaloids are compounds that can be co-purified along with the product. Such contaminants should be removed from the final product, using conventional purification processes [89-90].

Although in some cases, plant-specific N-glycosylation is considered an advantage as it functions as an intrinsic adjuvant for the mucosal vaccines, there are some procedures to limit the plant glycosylation including, site-directed mutations in potential N-glycosylation sites, RNA interference, coexpressing specific human glycosyltransferases, exploitation of specific knockout transgenic lines that lacks complex glycosids including xylose and fucose transferring enzymes, and adding the ER retention signal for preventing protein transfer to Golgi apparatus for further complex glycosylation [91]. In a recent strategy, an in vivo enzymatic deglycosylation based on transient co-expression of peptide-N-glycosidase F (PNGase F) from Flavobacterium meningosepticum was applied with the target of interest. This strategy has been successfully used for producing a malaria vaccine candidate based on Pfs $48 / 45$ antigen and also an anthrax vaccine candidate using PA83 protective antigen in $N$. benthamiana. The resulted non-Nglycosylated recombinant proteins have been shown to preserve their native conformation and immunological properties [9293].

\section{CONCLUSION}

In conclusion, plant transient expression has demonstrated a great potential to be used as a biofactory for production of valuable pharmaceutical proteins such as vaccines. Recent progress in clinical trials, in addition to the other advantages of such expression system including time efficiency, production of VLPs, high level of expression and cost-effectiveness, have made plant expression system an appropriate candidate for combating pandemic diseases such as influenza.

\section{ACKNOWLEDGEMENT}

We would like to thank Mr. Farzin Mohammadzadeh for his critical reading and English corrections.

\section{CONFLICT OF INTEREST}

The authors declare that they have no conflict of interest.

\section{REFERENCES}

1. CARE. Facts About Children and Poverty. 2011. (http://www.care.org/work/poverty/child-poverty/facts).

2. Sijmons PC, Dekker BM, Schrammeijer B, Verwoerd TC, Van Den Elzen

PJ, Hoekema A. Production of correctly processed human serum albumin in transgenic plants. Biotechnology (N Y). 1990;8(3):217-21. doi:10.1038/nbt0390-217

3. Loh HS, Green BJ, Yusibov V. Using transgenic plants and modified plant viruses for the development of treatments for human diseases. Curr Opin Virol.2017;26:81-89. doi: 10.1016/j.coviro.2017.07.019.

4. Ehsani P, Meunier A, Nato F, Jafari A, Nato A, Lafaye P. Expression of anti human IL-4 and IL-6 scFvs in transgenic tobacco plants. Plant Mol Biol. 2003;52(1):17-29. doi:10.1023/A:1023902407855

5. Yusibov VM. Mamedov TG. Plants as an Alternative System for Expression of Vaccine Antigens. Proc of ANAS (Biol Sci). 2010; 65(5-6): 195-200.

6. Mohammadzadeh S, Roohvand F, Ajdary S, Ehsani P, Salmanian AH. Heterologous Expression of Hepatitis C Virus Core Protein in Oil Seeds of Brassica napus L. Jundishapur J Microbiol. 2015;8(11):e25462. doi:10.5812/jjm.25462

7. Hefferon K. Clinical Trials Fuel the Promise of Plant-Derived Vaccines. Am J Clin Med. 2010;7(1):30-7.

8. Daniell $H$, Singh ND, Mason $H$, Streatfield SJ. Plant-made vaccine antigens and biopharmaceuticals. Trends Plant Sci. 2009;14(12):669-79. doi:10.1016/j.tplants.2009.09.009.

9. Howard JA, Hood EE. Commercial Plant-Produced Recombinant Protein Products. vol 68. 2014

10. Komarova TV, Baschieri S, Donini M, Marusic C, Benvenuto E Dorokhov YL. Transient expression systems for plant-derived biopharmaceuticals. Expert Rev Vaccines. 2010;9(8):859-76. doi:10.1586/erv.10.85

11. Owen MRL, Pen J (eds). Transgenic Plants: A Production System for Industrial and Pharmaceutical Proteins. 1996. John Wiley, Chichester, UK.

12. Rao AQ, Bakhsh A, Kiani S, Shahzad K, Shahid AA, Husnain T et al. The myth of plant transformation. Biotechnol Adv. 2009;27(6):753-63. doi:10.1016/j.biotechadv.2009.04.028

13. Gelvin SB. Agrobacterium-Mediated Plant Transformation: the Biology behind the "Gene-Jockeying" Tool. Microbiol Mol Biol Rev. 2003;67(1):16-37. doi:10.1128/mmbr.67.1.16-37.2003.

14. Ow DW, DE Wet JR, Helinski DR, Howell SH, Wood KV, Deluca M. Transient and stable expression of the firefly luciferase gene in plant cells and transgenic plants. Science. 1986;234(4778):856-9. doi:10.1126/science.234.4778.856.

15. Horsch RB, Klee HJ. Rapid assay of foreign gene expression in leaf discs transformed by Agrobacterium tumefaciens: Role of T-DNA borders in the transfer process. Proc Natl Acad Sci U S A. 1986;83(12):4428-32.

16. Thuenemann EC, Lenzi P, Love AJ, Taliansky M, Becares M, Zuniga S et al. The use of transient expression systems for the rapid production of virus-like particles in plants. Curr Pharm Des. 2013;19(31):5564-73.

17. Sainsbury F, Thuenemann EC, Lomonossoff GP. pEAQ: versatile expression vectors for easy and quick transient expression of heterologous proteins in plants. Plant Biotechnol J. 2009;7(7):682-93. doi:10.1111/j.1467-7652.2009.00434.x.

18. Hunt K. Plant-made influenza virus-like-particles (VLPs) activate dendritic cells and promote Type 1 immune responses: McGill University; 2016.

19. Mehrotra S, Goyal V. Agrobacterium-mediated gene transfer in plants and biosafety considerations. Appl Biochem Biotechnol. 2012;168(7):195375. doi:10.1007/s12010-012-9910-6

20. Bendandi M, Marillonnet S, Kandzia R, Thieme F, Nickstadt A, Herz S et al. Rapid, high-yield production in plants of individualized idiotype vaccines for non-Hodgkin's lymphoma. Ann Oncol. 2010;21(12):2420-7. doi:10.1093/annonc/mdq256.

21. D'Aoust MA, Lavoie PO, Belles-Isles J, Bechtold N, Martel M, Vezina LP. Transient expression of antibodies in plants using syringe agroinfiltration. Methods Mol Biol. 2009;483:41-50. doi:10.1007/978-159745-407-0_3.

22. Deen SS. A Plant-based Recombinant PlpE Vaccine for Fowl Cholera. (Thesis) Monash University, Melbourne, Australia. 2012.

23. Shoji Y, Prokhnevsky A, Leffet B, Vetter N, Tottey S, Satinover S et al. Immunogenicity of $\mathrm{H} 1 \mathrm{~N} 1$ influenza virus-like particles produced in Nicotiana benthamiana. Hum Vaccin Immunother. 2015;11(1):118-23. doi: $10.4161 /$ hv.34365

24. D'Aoust MA, Lavoie PO, Couture MM, Trepanier S, Guay JM, Dargis $\mathrm{M}$ et al. Influenza virus-like particles produced by transient expression in Nicotiana benthamiana induce a protective immune response against a lethal viral challenge in mice. Plant Biotechnol J. 2008;6(9):930-40. doi:10.1111/j.1467-7652.2008.00384.x.

25. da Cunha NB, Vianna GR, da Almeida Lima T, Rech E. Molecular farming of human cytokines and blood products from plants: challenges in 
biosynthesis and detection of plant-produced recombinant proteins. Biotechnol J. 2014;9(1):39-50. doi: 10.1002/biot.201300062.

26. Li J, Chen M, Liu X-W, Zhang H-C, Shen FF, Wang GP. Transient expression of an active human interferon-beta in lettuce. Scientia Horticulturae. 2007;112(3):258-65. doi:10.1016/j.scienta.2006.12.047.

27. Krenek P, Samajova O, Luptovciak I, Doskocilova A, Komis G, Samaj J. Transient plant transformation mediated by Agrobacterium tumefaciens: Principles, methods and applications. Biotechnol Adv. 2015 Nov 1;33(6 Pt 2):1024-42. doi:10.1016/j.biotechadv.2015.03.012.

28. Karner S. Plant Molecular biology opportunities and challenges JRC European commission. 2008.

29. Pitzschke A, Hirt H. New insights into an old story: Agrobacteriuminduced tumour formation in plants by plant transformation. EMBO J. 2010;29(6):1021-32. doi:10.1038/emboj.2010.8

30. Goodin MM. Zaitlin D, Naidu RA, Lommel SA. Nicotiana benthamiana: Its History and Future as a Model for Plant-Pathogen Interactions. Mol Plant Microbe Interact. 2008;21(8):1015-26. doi:10.1094/ MPMI -21-8-1015.

31. Kuchuk N, Komarnitski I, Shakhovsky A, Gleba Y. Genetic transformation of Medicago species by Agrobacterium tumefaciens and electroporation of protoplasts. Plant Cell Rep. 1990;8(11):660-3. doi:10.1007/BF00269987.

32. Brereton HM, Chamberlain D, Yang R, Tea M, McNeil S, Coster DJ et al. Single chain antibody fragments for ocular use produced at high levels in a commercial wheat variety. J Biotechnol. 2007;129(3):539-46. doi:10.1016/j.jbiotec.2007.01.008.

33. Vasylenko M, Ovcharenko O, Gleba Y, Kuchuk N. Production of cybrids in Brassicaceae species. Methods Mol Biol. 2006;318:219-32. doi:10.1385/1-59259-959-1:219.

34. Qu F, Morris TJ. Efficient Infection of Nicotiana benthamiana by Tomato bushy stunt virus Is Facilitated by the Coat Protein and Maintained by p19 Through Suppression of Gene Silencing. Mol Plant Microbe Interact. 2002;15(3):193-202.

35. Dorokhov YL, Ivanov PA, Komarova TV, Skulachev MV, Atabekov JG. An internal ribosome entry site located upstream of the crucifer-infecting tobamovirus coat protein $(\mathrm{CP})$ gene can be used for CP synthesis in vivo. J Gen Virol. 2006;87(Pt 9):2693-7. doi:10.1099/vir.0.82095-0.

36. Werner S, Breus O, Symonenko Y, Marillonnet S, Gleba Y. High-level recombinant protein expression in transgenic plants by using a doubleinducible viral vector. Proc Natl Acad Sci U S A. 2011;108(34):14061-6. doi:10.1073/pnas.1102928108.

37. Mathur J, Koncz C. PEG-mediated protoplast transformation with naked DNA. Arabidopsis Protocols. Springer; 1998. p. 267-76.

38. Bates GW. Plant Transformation via Protoplast Electroporation. In: Hall RD, editor. Plant Cell Culture Protocols. Totowa, NJ: Humana Press; 1999. p. 359-66.

39. Avesani L, Marconi G, Morandini F, Albertini E, Bruschetta M, Bortesi $\mathrm{L}$ et al. Stability of Potato virus $\mathrm{X}$ expression vectors is related to insert size: implications for replication models and risk assessment. Transgenic Res. 2007;16(5):587-97. doi:10.1007/s11248-006-9051-1.

40. Mohammadzadeh S, Khabiri A, Roohvand F, Memarnejadian A, Salmanian AH, Ajdary S et al. Enhanced-Transient Expression of Hepatitis C Virus Core Protein in Nicotiana tabacum, a Protein With Potential Clinical Applications. Hepat Mon. 2014;14(11):e20524. doi:10.5812/hepatmon.20524

41. Beihaghi M, Marashi H, Bagheri A, Sankian M. Transient expression of CCL21 as recombinant protein in tomato. Biotechnol Rep (Amst). 2018;17:10-5. doi:10.1016/j.btre.2017.11.007

42. Ohadi M, Rasouli R, Darzi-Eslam E, Jafari A, Ehsani P. Expression of Shigella flexneri ipaB Gene in Tobacco. Avicenna J Med Biotechnol. 2013;5(2):118.

43. Gleba Y, Klimyuk V, Marillonnet S. Magnifection - a new platform for expressing recombinant vaccines in plants. Vaccine. 2005;23(17):2042-8. doi:10.1016/j.vaccine.2005.01.006

44. Gleba Y, Klimyuk V, Marillonnet S. Viral vectors for the expression of proteins in plants. Curr Opin Biotechnol. 2007;18(2):134-41. doi:10.1016/j.copbio.2007.03.002

45. Mortimer CL, Dugdale B, Dale JL. Updates in inducible transgene expression using viral vectors: from transient to stable expression. Curr Opin Biotechnol. 2015;32:85-92. doi:10.1016/j.copbio.2014.11.009

46. Gleba YY, Tusé D, Giritch A. Plant viral vectors for delivery by Agrobacterium. Curr Top Microbiol Immunol.2014; 375: 155-192. doi:10.1007/82_2013_352

47. Chen Q, Lai $\bar{H}$, Hurtado J, Stahnke J, Leuzinger K, Dent $M$. Agroinfiltration as an Effective and Scalable Strategy of Gene Delivery for
Production of Pharmaceutical Proteins. Adv Tech Biol Med. 2013;1(1). doi:10.4172/atbm.1000103.

48. Kagale S, Uzuhashi S, Wigness M, Bender T, Yang W, Borhan MH et al. TMV-Gate vectors: gateway compatible tobacco mosaic virus based expression vectors for functional analysis of proteins. Sci Rep. 2012;2:874. doi:10.1038/srep00874.

49. Sainsbury F, Sack M, Stadlmann J, Quendler H, Fischer R, Lomonossoff GP. Rapid transient production in plants by replicating and non-replicating vectors yields high quality functional anti-HIV antibody. PloS one. 2010;5(11):e13976. doi:10.1371/journal.pone.0013976.

50. Peyret H, Lomonossoff GP. The pEAQ vector series: the easy and quick way to produce recombinant proteins in plants. Plant mol biol. 2013;83(12):51-8. doi:10.1007/s11103-013-0036-1

51. Chen Q, Lai H. Plant-derived virus-like particles as vaccines. Hum Vaccin Immunother. 2013;9(1):26-49. doi:10.4161/hv.22218.

52. Sharon A. Fraunhofer USA News Brief - FHCMI - In: (CMI) FCfMI, editor.January 2011.

53. Schillberg S, Twyman RM, Fischer R. Opportunities for recombinant antigen and antibody expression in transgenic plants--technology assessment. Vaccine.

doi:10.1016/j.vaccine.2004.11.002

54. Sharon A. Center for Manufacturing Innovation. In: USA CS-F, editor.2009.

55. Soria-Guerra RE, Moreno-Fierros L, Rosales-Mendoza S. Two decades of plant-based candidate vaccines: a review of the chimeric protein approaches. Plant Cell Rep. 2011;30(8):1367-82. doi:10.1007/s00299-0111065-3.

56. Huang Z, Santi L, LePore K, Kilbourne J, Arntzen CJ, Mason HS Rapid, high-level production of hepatitis B core antigen in plant leaf and its immunogenicity in mice. Vaccine. 2006;24(14):2506-13. doi:10.1016/j.vaccine.2005.12.024

57. Gleba Y. Transient expression technologies for plants 2012.

58. Liu Clarke J, Paruch L, Dobrica MO, Caras I, Tucureanu C, Onu A et al. Lettuce-produced hepatitis $\mathrm{C}$ virus E1E2 heterodimer triggers immune responses in mice and antibody production after oral vaccination. Plant Biotechnol J. 2017;15(12):1611-1621. doi: 10.1111/pbi.12743

59. Mardanova ES, Kotlyarov RY, Kuprianov VV, Stepanova LA, Tsybalova LM, Lomonosoff GP et al. Rapid high-yield expression of a candidate influenza vaccine based on the ectodomain of M2 protein linked to flagellin in plants using viral vectors. BMC Biotechnol. 2015;15(1):42. doi:10.1186/s12896-015-0164-6

60. Beiss V, Spiegel H, Boes A, Kapelski S, Scheuermayer M, Edgue G et al. Heat-precipitation allows the efficient purification of a functional plantderived malaria transmission-blocking vaccine candidate fusion protein. Biotechnol Bioeng. 2015;112(7):1297-305. doi:10.1002/bit.25548

61. Veerapen VP, van Zyl AR, Wigdorovitz A, Rybicki EP, Meyers AE. Novel expression of immunogenic foot-and-mouth disease virus-like particles in Nicotiana benthamiana. Virus Res. 2018;244:213-7. doi:10.1016/j.virusres.2017.11.027

62. Major D, Chichester JA, Pathirana RD, Guilfoyle K, Shoji Y, Guzman $\mathrm{CA}$ et al. Intranasal vaccination with a plant-derived $\mathrm{H} 5 \mathrm{HA}$ vaccine protects mice and ferrets against highly pathogenic avian influenza virus challenge. Hum Vaccin Immunother. 2015;11(5):1235-43. doi:10.4161/21645515.2014.988554

63. Mathew LG, Herbst-Kralovetz MM, Mason HS. Norovirus Narita 104 virus-like particles expressed in Nicotiana benthamiana induce serum and mucosal immune responses. Biomed Res Int. 2014;2014:807539. doi:10.1155/2014/807539

64. Wigdorovitz A, Perez Filgueira DM, Robertson N, Carrillo C, Sadir AM, Morris TJ et al. Protection of mice against challenge with foot and mouth disease virus (FMDV) by immunization with foliar extracts from plants infected with recombinant tobacco mosaic virus expressing the FMDV structural protein VP1. Virology. 1999;264(1):85-91. doi:10.1006/viro.1999.9923.

65. Lico C, Chen Q, Santi L. Viral vectors for production of recombinant proteins in plants. J Cell Physiol. 2008;216(2):366-77. doi:10.1002/jcp. 21423 .

66. Mohammadzadeh S, Roohvand F, Memarnejadian A, Jafari A, Ajdary S, Salmanian A-H et al. Co-expression of hepatitis $\mathrm{C}$ virus polytope-HBsAg and p19-silencing suppressor protein in tobacco leaves. Pharm Biol. 2016;54(3):465-73. doi:10.3109/13880209.2015.1048371

67. Dorokhov YL, Sheveleva AA, Frolova OY, Komarova TV, Zvereva AS, Ivanov PA et al. Superexpression of tuberculosis antigens in plant leaves. Tuberculosis (Edinb). 2007;87(3):218-24. doi:10.1016/j.tube.2006.10.001. 68. Yang M, Sun H, Lai H, Hurtado J, Chen Q. Plant-produced Zika virus 
envelope protein elicits neutralizing immune responses that correlate with protective immunity against Zika virus in mice. Plant Biotechnol J. 2018;16(2):572-80. doi:10.1111/pbi. 12796

69. Scotti N, Rybicki EP. Virus-like particles produced in plants as potential vaccines. Expert Rev Vaccines. 2013;12(2): 211-24. doi:10.1586/erv.12.147 70. Cummings JF, Guerrero ML, Moon JE, Waterman P, Nielsen RK, Jefferson $\mathrm{S}$ et al. Safety and immunogenicity of a plant-produced recombinant monomer hemagglutinin-based influenza vaccine derived from influenza A (H1N1) pdm09 virus: a Phase 1 dose-escalation study in healthy adults. Vaccine. 2014;32(19):2251-9. doi:10.1016/j.vaccine.2013.10.017

71. Santi L, Batchelor L, Huang Z, Hjelm B, Kilbourne J, Arntzen CJ et al. An efficient plant viral expression system generating orally immunogenic Norwalk virus-like particles. Vaccine. 2008;26(15):1846-54. doi:10.1016/j.vaccine.2008.01.053.

72. Kushnir N, Streatfield SJ, Yusibov V. Virus-like particles as a highly efficient vaccine platform: diversity of targets and production systems and advances in clinical development. Vaccine. 2012;31(1):58-83. doi:10.1016/j.vaccine.2012.10.083.

73. Noad R, Roy P. Virus-like particles as immunogens. Trends Microbiol. 2003;11(9):438-44. doi:10.1016/S0966-842X(03)00208-7

74. Masavuli MG, Wijesundara DK, Torresi J, Gowans EJ, Grubor-Bauk B. Preclinical development and production of virus-like particles as vaccine candidates for hepatitis C. Front Microbiol. 2017;8:2413. doi: $10.3389 /$ fmicb. 2017.02413

75. Marsian J, Lomonossoff GP. Molecular pharming_-VLPs made in $\begin{array}{llll}\text { plants. } & \text { Curr } & \text { Opin } & \text { Biotechnol. }\end{array}$ doi:10.1016/j.copbio.2015.12.007

76. Kim H-S, Jeon J-H, Lee KJ, Ko K. N-glycosylation modification of plant-derived virus-like particles: an application in vaccines. Biomed Res Int. 2014;2014:249519. doi: 10.1155/2014/249519

77. Kalnciema I, Skrastina D, Ose V, Pumpens P, Zeltins A. Potato virus Ylike particles as a new carrier for the presentation of foreign protein stretches. Mol Biotechnol. 2012;52(2):129-39. doi:10.1007/s12033-0119480-9.

78. Gil F, Reytor E, Perez-Filgueira DM, Escribano JM. Multimerization of peptide antigens for production of stable immunogens in transgenic plants. Journal Biotechnol. 2007;128(3):512-8. doi:10.1016/j.jbiotec.2006.11.001.

79. Hefferon KL. Plant virus expression vectors set the stage as production platforms for biopharmaceutical proteins. Virology. 2012;433(1):1-6. doi:10.1016/j.virol.2012.06.012

80. Banik S, Mansour AA, Suresh RV, Wykoff-Clary S, Malik M, McCormick AA et al. Development of a multivalent subunit vaccine against tularemia using tobacco mosaic virus (TMV) based delivery system. PloS one. $2015 ; 10(6)$ :e0130858. doi:10.1371/journal.pone. 0130858

81. Gasanova T, Petukhova N, Ivanov P. Chimeric particles of tobacco mosaic virus as a platform for the development of next-generation nanovaccines. Nanotechnologies in Russia. 2016;11(3-4):227-36. doi: $10.1134 / \mathrm{S} 1995078016020051$
82. Marconi G, Albertini E, Barone P, De Marchis F, Lico C, Marusic C et al. In planta production of two peptides of the Classical Swine Fever Virus (CSFV) E2 glycoprotein fused to the coat protein of potato virus X. BMC Biotechnol. 2006;6(1):29. doi:10.1186/1472-6750-6-29

83. Howard JA, Hood EE. Commercial plant-produced recombinant protein products. Springer; 2016

84. Shoji Y, Jones RM, Mett V, Chichester JA, Musiychuk K, Sun X et al. A plant-produced $\mathrm{H} 1 \mathrm{~N} 1$ trimeric hemagglutinin protects mice from a lethal influenza virus challenge. Hum Vaccin Immunother. 2013;9(3):553-60 doi: $10.4161 /$ hv. 23234

85. Yusibov V, Hooper DC, Spitsin SV, Fleysh N, Kean RB, Mikheeva T et al. Expression in plants and immunogenicity of plant virus-based experimental rabies vaccine. Vaccine. 2002;20(25-26):3155-64 doi:10.1016/S0264-410X(02)00260-8

86. Tacket CO. Plant-based oral vaccines: results of human trials. Curr Top Microbiol Immunol. 2009;332:103-17. doi:10.1007/978-3-540-70868-1 6.

87. Takagi H, Hiroi T, Yang L, Tada Y, Yuki Y, Takamura K et al. A ricebased edible vaccine expressing multiple $\mathrm{T}$ cell epitopes induces oral tolerance for inhibition of Th2-mediated IgE responses. Proc Natl Acad Sci U S A. 2005;102(48):17525-30. doi:10.1073/pnas.0503428102.

88. Smart V, Foster PS, Rothenberg ME, Higgins TJ, Hogan SP. A plantbased allergy vaccine suppresses experimental asthma via an IFN-gamma and CD4+CD45RBlow $\mathrm{T}$ cell-dependent mechanism. $\mathrm{J}$ Immunol 2003;171(4):2116-26. doi:10.4049/jimmunol.171.4.2116

89. Lombardi R, Villani ME, Di Carli M, Brunetti P, Benvenuto E, Donini M. Optimisation of the purification process of a tumour-targeting antibody produced in N. benthamiana using vacuum-agroinfiltration. Transgenic Res. 2010;19(6):1083-97. doi:10.1007/s11248-010-9382-9.

90. Lai H, Engle M, Fuchs A, Keller T, Johnson S, Gorlatov S et al Monoclonal antibody produced in plants efficiently treats West Nile virus infection in mice. Proc Natl Acad Sci U S A. 2010;107(6):2419-24. doi:10.1073/pnas.0914503107.

91. Gomord V, Fitchette AC, Menu-Bouaouiche L, Saint-Jore-Dupas C, Plasson C, Michaud D et al. Plant-specific glycosylation patterns in the context of therapeutic protein production. Plant Biotechnol J. 2010;8(5):564-87. doi:10.1111/j.1467-7652.2009.00497.x.

92. Mamedov T, Ghosh A, Jones RM, Mett V, Farrance CE, Musiychuk K et al. Production of non-glycosylated recombinant proteins in Nicotiana benthamiana plants by co-expressing bacterial PNGase F. Plant Biotechnol J. 2012;10(7):773-82. doi:10.1111/j.1467-7652.2012.00694.x.

93. Mamedov T, Chichester JA, Jones RM, Ghosh A, Coffin MV, Herschbach $\mathrm{K}$ et al. Production of functionally active and immunogenic non-glycosylated protective antigen from Bacillus anthracis in Nicotiana benthamiana by co-expression with peptide-N-glycosidase F (PNGase F) of Flavobacterium meningosepticum. PloS one. 2016;11(4):e0153956. doi:10.1371/journal.pone.0153956. 